\title{
Минеральные виды Северной Карелии: рудные минералы Тикшеозерско-Елетьозерского комплекса и связанных с ним метасоматитов
}

Кулешевич Л.В.

ИГ Кар НЦ РАН, Петрозаводск, kuleshev@krc.karelia.ru

Аннотация. Тикшеозерско-Елетьозерский комплекс объединяет дифференцированные массивы щелочно-ультраосновных пород, карбонатиты, метасоматиты. Он сопровождается Р-Fe-Ti-оксидными, апатит-карбонатитовыми рудами, редкометалльно-редкоземельной минерализацией. Минеральные виды P-Fe-Ті-оксидных руд представлены титаномагнетитом, магнетитом, ульвитом, ильменитом, герцинитом, апатитом, титанитом, в зонах влияния щелочных пород встречается корунд. В карбонатитах установлены апа-

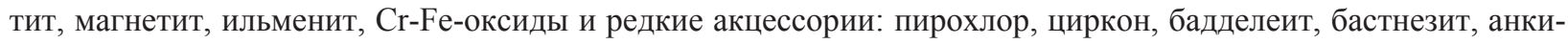
лит, карбоцернаит, стронциобарит. В карбонат-полевошпатовых метасоматитах встречаются Mn-Ti-магнетит, пирофанит-манганоильменит, перовскит, титанит, сульфиды; в фенитах - ярко-синий содалит.

Ключевые слова: Елетьозерско-Тикшеозерский комплекс, минеральное разнообразие, Карелия.

\section{Mineral species of North Karelia: ore minerals from the Tiksheozero-Yeletozero complex and associated metasomatic rocks}

\author{
Kuleshevich L.V. \\ IG KarRC RAS, Petrozavodsk, kuleshev@krc.karelia.ru
}

\begin{abstract}
The Tiksheozero-Yeletozero complex comprises differentiated alkaline-ultramafic rock massifs, carbonatites and metasomatic rocks. It is accompanied by P-Fe-Ti-oxide, apatite-carbonatite ores and rare metal-rare earth mineralization. The mineral types of P-Fe-Ti-oxide ores are represented by titanomagnetite, magnetite, ulvite, ilmenite, hercynite, apatite and titanite; corundum occurs in zones affected by alkaline rocks. The carbonatites were found to contain apatite, magnetite, ilmenite, $\mathrm{Cr}$-Fe-oxides and rare accessories such as pyrochlore, zircon, baddeleyite, bastnesite, ancylite, carbocernaite and strontiobarite. Mn-Ti-magnetite, pyrophanite-mangan-ilmenite, perovskite, titanite and sulphides occur in carbonate-feldspar metasomatic rocks. Bright-blue sodalite occurs in phenites.
\end{abstract}

Keywords: Yeletozero-Tiksheozero complex, mineral diversity, Karelia.

\section{Введение}

Тикшеозерско-Елетьозерский комплекс щелочно-ультраосновных пород объединяет Тикшеозерский и Елетьозерский дифференцированные массивы, расположенные в Лоухском районе Карелии. Детальная разведка и оценка массивов проводились в 30-х-80-х годах прошлого века СЗГУ, Северной ГЭ, ИГ КарНЦ РАН. Изучением строения, магматизма, рудной минерализации, вопросами обогащения руд занимались С.И. Зак (1957), А.И. Богачев (1963), А.А. Кухаренко (1969), А.И. Кириллов, С.Ф. Клюнин, Н.Н. Холодилов, Г.П. Сафронова, В.В. Щипцов, Путинцева Е.В. и другие геологи. Тикшеозерско-Елетьозерский комплекс (ТЕК) дифференцирован от ультрабазитов до нефелиновых сиенитов, в Тикшеозерском массиве развиты карбонатиты. Породы комплекса $\left(\mathrm{PR}_{1} \mathrm{e}-\mathrm{t}\right)$ имеют палеопротерозойский возраст 2.0 млрд. лет, свекофеннские метаморфические преобразования происходили $\sim 1.77-1.78$ млрд. лет.

\section{Минералогия P-Fe-Ti-окисных руд Елетьозерского массива}

Елетьозерский массив представляет собой расслоенную интрузию, погружающуюся в ВСВ направлении, с мощностью увеличивающейся от сотни метров в западной части до 3-3.5 км в восточной части. К массиву приурочено Елетьозерское месторождение титаномагнетитовых руд, обнаруженное в 1933-1937 годах и разведываемое в 1954-57 годах ГУ «Севзапгеология» (С.И. Заком, Ю.Ф. Киселевым и др.). В строении массива преобладают основные и ультраосновные породы ранних фаз внедрения, слагающие его периферическую часть, в центре - залегают породы повышенной щелочности (монцониты, сиениты, нефелиновые сиениты), образовавшиеся позднее 

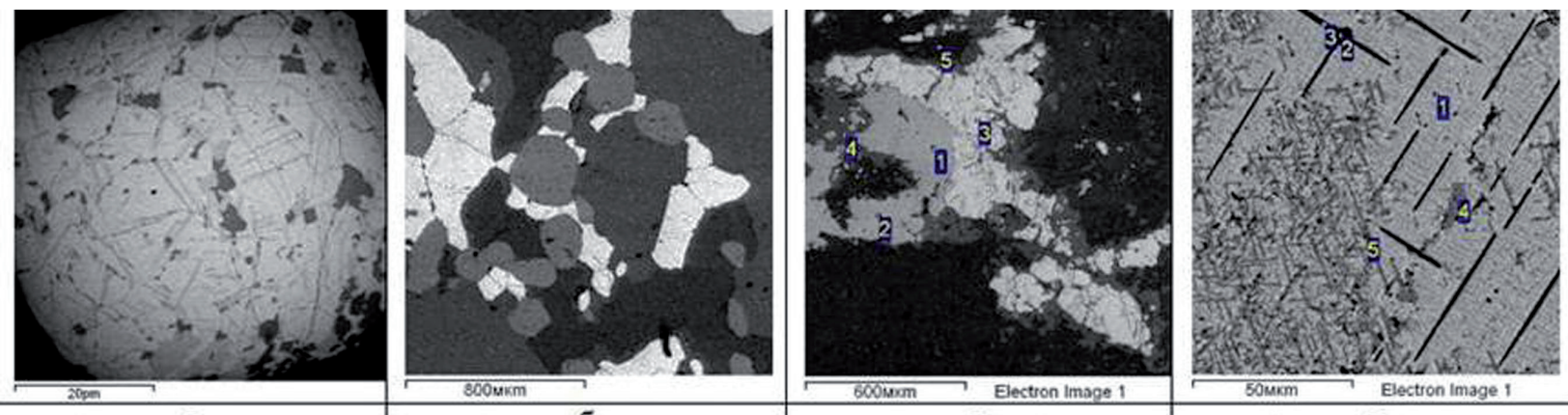

6
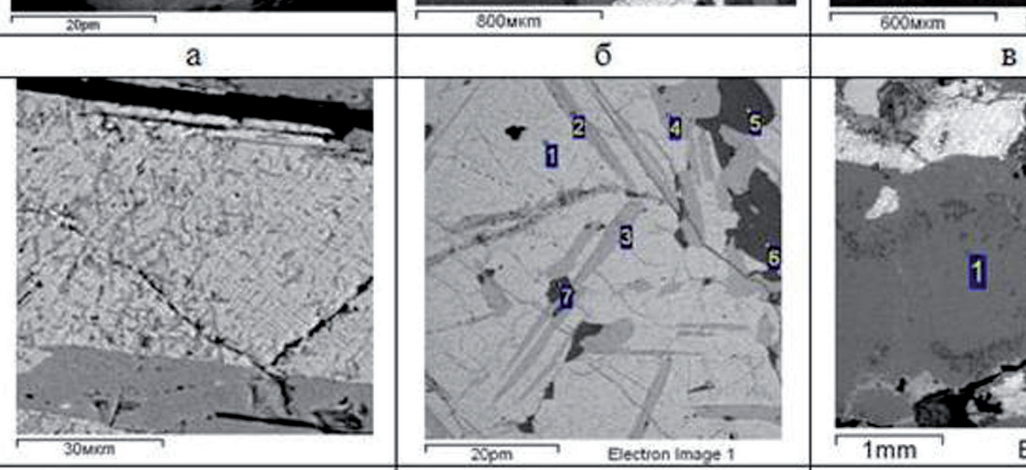

д
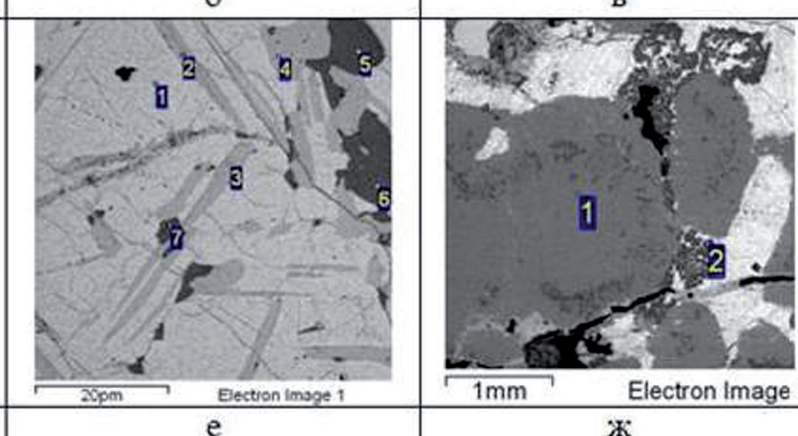

Рис. 1. Титаномагнетитовые руды.

a - богатая титаномагнетитовая руда; б - вкрапленная апатит-титаномагнетитовая руда; в - вкрапленность титаномагнетита (3) и ильменита (1-2) замещается титанитом (4,5); г - в титаномагнетите (1) ламелли ульвита, ильменита (4-5) и герцинита (2-3); д - титаномагнетит с тонким распадом ульвита, пластинками ильменита (серый) и герцинита (черный); е - ильменит-титаномагнетитовая руда (1 - титаномагнетит, 2-4 - ильменит, 5-7 - герцинит); ж - роговая обманка (1) с мелким корундом, в титаномагнетите - более крупный корунд (2); 3 - роговая обманка (темно-серая), титаномагнетит (белый), корунд (1-3).

Fig. 1. Titanomagnetite ores.

a - rich titanomagnetite ore; 6 - disseminated apatite-titanomagnetite ore; в - disseminated titanomagnetite (3) and ilmenite (1-2) is replaced by titanite $(4,5) ; \Gamma$ - in titanomagnetite (1) lamella of ulvite, ilmenite (4-5) and hercynite (2-3); д - titanomagnetite with a subtle decay of ulvite, plates of ilmenite (grey) and hercynite (black); e - ilmenitetitanomagnetite ore (1 - titanomagnetite, 2-4 - ilmenite, 5-7 - gerzina); $\%$ - hornblende (1) with a fine corundum, magnetite - larger corundum (2); 3 - hornblende (dark grey), titanomagnetite (white), corundum (1-3).

(Богачев и др., 1963). На первом этапе внедрились перидотиты, пироксениты и габбро с апатиттитаномагнетитовым оруденением, на втором - щелочные породы. Продуктивный горизонт Fe-Tiруд приурочен к зоне с тонким ритмичным переслаиванием (плагиоклазитов - габбро - оливиновых габбро - перидотитов). Массив секут щелочные дайки и пегматиты, развитые вокруг сиенитового ядра. Щелочные породы оказывают влияние на породы ранних фаз внедрения и руды. Для них характерны обогащенность РЗЭ, $\mathrm{Ba}, \mathrm{Sr}, \mathrm{Nb}$ и присутствие ряда минералов необычного состава, включающих эти элементы (по работам Л.Н. Когарко с соавторами).

$\mathrm{Ti-Fe-окисные} \mathrm{pуды} \mathrm{в} \mathrm{Елетьозерском} \mathrm{массиве} \mathrm{установлены} \mathrm{на} \mathrm{проявлениях} \mathrm{Нято-Вара,} \mathrm{Межозер-}$ ный (западный участок) и Сури-Вара (восточный). Они образуют крутопадающие пластообразные линзующиеся залежи, объединяемые в Елетьозерское месторождение (Минерально..., 2005). Руды среднезернистые с вкрапленной, полосчатой и массивной текстурами, содержат 10-80\% Fe-Ті-оксидов. Содержание $\mathrm{Fe}_{\text {вал }}$ в них составляет 15.32-37.5 \%, среднее $\mathrm{TiO}_{2}-10.3 \%, \mathrm{~V}_{2} \mathrm{O}_{5} 0.06-0.18$ \% (Щипцов и др., 2009; http://nedrark.karelia.ru/mnia/titan_karelia.htm).

Богатые титаномагнетитовые руды (рис. 1 а) содержат титаномагнетит и ильменит. Титаномагнетит в свою очередь в зависимости от раскристаллизации содержит пластинки и неправильные выделения ильменита, а также пластинки шпинели герцинитового ряда. Средний состав изученной богатой руды: $\mathrm{FeO} 56.81 \%, \mathrm{TiO}_{2} 15.75 \%, \mathrm{Al}_{2} \mathrm{O}_{3} 6.65 \%, \mathrm{MgO} 2.47 \%$. В слабо перекристаллизованной руде (1-тип) в титаномагнетите с тонкими почти не заметными ламеллями установле- 
ны примеси $\mathrm{Al} 1.14$ \%, Mg 0.58 \%, V 0.55 \% и высокое содержание Ti 9.86-4.8 \% (рис. 1 г). Ванадий концентрируется преимущественно в титаномагнетите. Начальный распад при остывании приводит к обособлению тонких более четких ламеллей ульвита $\mathrm{TiFe}_{2} \mathrm{O}_{4}$, а затем образованию более крупных пластинок ильменита $\mathrm{FeTiO}_{3}$ и $\mathrm{Mg}$-герцинита $(\mathrm{Mg}, \mathrm{Fe}) \mathrm{Al}_{2} \mathrm{O}_{4}$ (рис. 1 г, д).

В более раскристаллизованной руде (2-тип) (рис. 1 е) в магнетите выделяются крупные пластинки ильменита и его овальные обособления (ульвит отсутствует). Титаномагнетит освобождается от титана, в нем снижается концентрация примесей $\mathrm{Ti}$ (до 0.5-0.68 \%), Mg, Al, но V сохраняется. Крупные пластинки ильменита $\mathrm{FeTiO}_{3}$ содержат примесь $\mathrm{Mn}$ 0.86-1.24 \%, Mg 1.16-1.72 \%, более крупные овальные зерна - до 2.88 \% Mn. Одновременно в магнетите выделяются неправильные зерна $\mathrm{Mg}$-герцинита $(\mathrm{Mg}, \mathrm{Fe}) \mathrm{Al}_{2} \mathrm{O}_{4}$ и ламелли $\mathrm{FeAl}_{2} \mathrm{O}_{4}$.

В более интенсивно перекристаллизованных при метаморфизме рудах (3-тип) титаномагнетит и ильменит замещаются титанитом (рис. 1 в). Пироксен замещается роговой обманкой. Выделяется акцессорный циркон и вкрапленные сульфиды.

Вкрапленные апатит-титаномагнетитовые руды встречаются на тех же трех рудных объектах. Наиболее обогащены апатитом Ti-Fe-руды с содержанием $\mathrm{TiO}_{2}>8.0 \%$, где апатит выделяется в срастании с магнетитом и ильменитом (Минерально..., 2006). Для подобных руд (4 тип) характерно присутствие титаномагнетита (Тi 5.56-9.25\%, V 0.56-0.68 \%, примеси Al, Mg) и F-OH-апатита (рис. 1 б). Содержание $\mathrm{P}_{2} \mathrm{O}_{5}$ в руде достигает $9.06 \%$. На границе с апатитом образуется биотит с высоким содержанием Тi (до 4-5.43 \%) и Се $(2.67 \%$ ) и роговая обманка $(\mathrm{Ti}-3.42 \%)$.

В титаномагнетовых и апатит-титаномагнетитовых рудах встречаются редкие сульфиды (пирротин, халькопирит). В перекристаллизованных рудах с титанитом присутствует вкрапленность пирротина, халькопирита, Со-пентландита, редкие зерна галенита, сфалерита, микронные зерна ре-

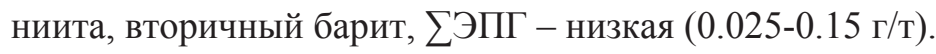

Весьма специфичны изменения титаномагнетитовых руд под влиянием щелочных пород. При этом выделяется корунд 2-х генераций: мелкий - в Na-Cl-содержащем высокоглиноземистом амфиболе и более крупный - в прожилках, секущих магнетит (рис. 1 ж, з). В этих рудах выделяется также вторичный пластинчатый стронциобарит ( $\mathrm{Sr} 2.65 \%$ ).

\section{Рудная минерализация Тикшеозерского массива}

Тикшеозерский массив имеет неправильную форму и разбит на три блока (Щипцов и др., 2012). Массив дифференцирован, он объединяет породы нескольких фаз внедрения, его формирование завершается внедрением карбонатитов и разнообразных щелочно-силикатно-карбонатных метасоматитов. С карбонатитами связаны апатитовые руды, карбонатное сырье, редкометалльная и редкоземельная минерализация.

Anaтитые руды карбонатитов (или апатит-карбонатные) приурочены к центральной части Тикшеозерского массива, участку Карбонатитовому, и пространственно совмещены с ним (Минерально..., 2006; Щипцов и др., 2012). Ширина выхода карбонатитов меняется от 600 м до 30 м; протяженность достигает 5.4 км. В экзоконтактакте карбонатитов развиты ореолы слюдяных и амфибол-карбонатных метасоматитов по пироксенитам и щелочным породам, мощность их от нескольких - до 10 м. Прогнозные ресурсы $\mathrm{P}_{2} \mathrm{O}_{5}$ (при среднем содержании $\mathrm{P}_{2} \mathrm{O}_{5} 4.18 \%$ ) были оценены до глубины 300 м в количестве 40.2 млн. т категории (Р1+P2). Апатит-франколитовые руды с более высоким содержанием $\mathrm{P}_{2} \mathrm{O}_{5}$ до $16.12 \%$ известны в южной части. Карбонатиты и апатитовые руды изучались Ю.М. Кирнарским, Н.Р. Холодиловым, С.Ф. Клюниным, Г.П. Сафроновой, В.В. Щипцовым и др. Апатит-карбонатные руды представляют собой светло-серые, мелко- или среднезернистые породы с полосчатой, массивной или пятнистой текстурой. Они содержат карбонаты (кальцит, доломит - до 70-90 \%), апатит - 5-20 \%, оксиды (магнетит, ильменит, Cr-Fe-оксиды) - 5-7 \%, флогопит $\sim 1-3 \%$, пироксены и амфиболы $\sim 1-4 \%$ и единичные зерна редких акцессориев, таких как пирохлор, циркон, бадделеит и редкоземельных элементов. Кальцит содержит небольшие примеси $\mathrm{Mg}, \mathrm{Mn}$, иногда $\mathrm{Sr}$, доломит - незначительно Fe до 1-3.5 ат. \%. F-OH-содержащий апатит в карбонатитах выделяется в форме овальных зерен (0.1-0.2 см), их срастаний и хорошо ограненных удли- 
ненных кристаллов (до 1 см). Карбонатиты содержат включения кристаллов пирохлора, бадделеита, циркон, монацит, реже торит и оксид тория (Кулешевич, 2016). С апатитом ассоциирует титаномагнетит и ильменит. Крупные зерна магнетита ( $\mathrm{V}-1.2 \%, \mathrm{Mn}-0.84-1 \%$ ) с пластинками ильменита (Mn до 2.78 \%) замещаются титанитом. Встречаются также хроммагнетиты (Cr до 9.5-12.66 \%, Ti 0.94-2.43 \%, V 0.53, Zn до 0.94 (C-169, C-157).

\section{Редкометалльно-редкоземельная минерализация ТЕК}

В Елетьозерском массиве она установлена вблизи пегматитовых жил щелочных пород: суммарные содержания оксидов REE достигают 0.1-0.36 \% (проявление Елетьозерское-1; Минерально..., 2005). Щелочные пегматиты (Nb 95, Zr 123, Sr 738, Вa 1670 ppm) связаны с нефелиновыми сиенитами. На контакте с вмещающими породами пегматиты содержат до 40-50 \% крупнозернистых темноцветных силикатов (эгирин-авгит, диопсид, арфведсонит, биотит-флогопит) и акцессории - пирохлор, циркон, титанит. Наиболее высокие концентрации $\mathrm{Nb}_{2} \mathrm{O}_{5}$, были установлены в пегматитовых жилах. На участке Суривара в жиле № 1 пирохлоровая минерализация $\left(\mathrm{Nb}_{2} \mathrm{O}_{5}-0.10-0.56\right.$ \%, в среднем $0.18 \%, \mathrm{Ta}_{2} \mathrm{O}_{5} 0.008 \%$ ) оценена до глубины 150 м по категории $\mathrm{C}_{2}$ в $355.2 \mathrm{~T} \mathrm{Nb}_{2} \mathrm{O}_{5}$ ). По жиле № 2 минерализованная зона прослежена на 50 м при средней мощности 2.9 м и среднем содержании $\mathrm{Nb}_{2} \mathrm{O}_{5} 0.26 \%, \mathrm{ZrO}_{2}-0.02-0.39 \%$ (максимально достигая 0.5-1 \%, Минерально..., 2005).

Ti-Fe-концентраты так же бывают обогащены RE-REE (по работам B.В. Щипцова и др. за 2006 г.). В P-Ti-Fe-рудах концентрации RE и REE обычно повышается: $\mathrm{Nb}_{2} \mathrm{O}_{5}-$ в среднем до 0.15-0.23 \%, $\mathrm{Ta}_{2} \mathrm{O}_{5}-0.01-0.015 \%, \mathrm{ZrO}_{2}-0.13-0.3 \%$, Hf до 0.0046-0.03 \%, $\sum \mathrm{REE}$ (в оксидах) - до $0.07-0.1 \%$.

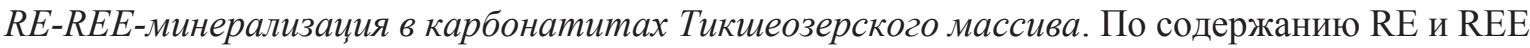
ультраосновные щелочные породы массива и карбонатиты выделяются повышенными концентрациями $\mathrm{Nb}$ (5-930 ppm), Ta (0.3-35.5), Sr (78-4363), Zr (50-336.5), Hf (0.2-12.6), REE (42-1261 ppm), Th (0.5-29.8), U (0.5-255), Ва (192-626 ppm). Редкометалльная минерализация тяготеет к такситовым карбонатитам с включениями силикатов (диопсида, флогопита, амфибола). Повышенные концентрации $\mathrm{Nb}, \mathrm{Sr}, \mathrm{Zr}$ в них обеспечиваются присутствием соответствующих минералов. Содержание $\mathrm{Sr}$ в апатит-содержащих карбонатитах наиболее высокое (до $1 \%$ ). Sr входит непосредственно в состав зонального апатита (до 1.52-1.78 \%) и ниобатов (Кулешевич, 2016). Кальцит содержит до $0.8 \% \mathrm{Sr}$. В барите примесь $\mathrm{Sr}$ достигает 1.16-8.6 \%, встречаются стронциобарит и стронцианит. В срастании с апатитом и монацитом установлены карбоцернаит $(\mathrm{Ca}, \mathrm{Na})(\mathrm{Sr}, \mathrm{Ce}, \mathrm{Ba})\left(\mathrm{CO}_{3}\right)_{2}$ и анкилит $\mathrm{Sr}(\mathrm{Ce}, \mathrm{La})\left(\mathrm{CO}_{3}\right)(\mathrm{OH})_{2} \mathrm{H}_{2} \mathrm{O}$.

Zr в карбонатитах распределен неравномерно (8-143 ppm), увеличивается до 337 ppm в амфибол-флогопит-содержащих метасоматитах, Hf - до 12.6 ppm. По данным (Минерально..., 2005), содержание $\mathrm{ZrO}_{2}$ достигает 0.1 \% (среднее 0.01-0.05 \%). Из минералов встречаются бадделеит и циркон. Циркон выделяется в апатите, кальците, замещает бадделеит, содержит примеси $\mathrm{Ce}, \mathrm{La}, \mathrm{Sc}, \mathrm{U}, \mathrm{Na}, \mathrm{Ca}, \mathrm{Hf}$.

Танталониобаты, Th и U минералы. Концентрация $\mathrm{Nb}$ в карбонатитах составляет 8-411 ppm,

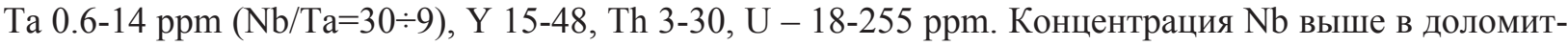
кальцитовых карбонатитах с включениями щелочных амфиболов и флогопита $(\mathrm{Nb}-0.04-0.08$ \%, $\mathrm{C}-169,155,146)$. Пирохлор $\mathrm{NaCaNb}_{2} \mathrm{O}_{6} \mathrm{~F}$ выделяется в апатите, в срастании с кальцитом, флогопитом. Состав пирохлора бывает очень не однороден (Франтц и др., 2011; Кулешевич, 2016). В нем существуют сложные гетеровалентные замещения: Са и $\mathrm{Na}$ замещаются $\mathrm{Sr}, \mathrm{Ce}, \mathrm{Y}, \mathrm{U}, \mathrm{Th}, \mathrm{Fe}$; $\mathrm{Nb}$ замещается Ta, Ti, реже $\mathrm{Si} ; \mathrm{F}$ - ОН. По данным микрозондового изучения установлены наиболее типичные изоморфные замещения в ряду пирохлор-бетафит: $\mathrm{Na}-\mathrm{Ca}-\mathrm{Nb}-\mathrm{Ta}-\mathrm{Ca}-(\mathrm{Na}-\mathrm{U})-(\mathrm{Ti}-\mathrm{Ta}-\mathrm{Nb})-$ фазы. Кристаллы пирохлора можно также разделить и по дополнительным анионам на 3 группы: 1 - с высокой концентрацией F (4.44-6.96 \%); 2 - с более низкой (F - 1-2.79 \% и группой $\mathrm{OH}^{-}$); 3 - ОН-содержащие (с дефицитом суммы). Наиболее распространены Na-Ca-Ti-Sr-Ta-Nb-пирохлоры. Сa-U-содержащий бетафит (U 0.71-4.69 \% и гатчеттолит с U 16.1-17.79 \%) встречаются реже. 
В C-153 обнаружены более редкие Тh-пирохлоры (Тh 3.72-9.97 \%) и Се-содержащие (0.8-5.92 \%). Th образует и собственные, но более редкие минералы (торит, оксид тория).

Редкоземельная минерализация в карбонатитах приурочена преимущественно к апатитовым рудам. REE-минералы представлены монацитом, рабдофанитом, бастнезитом-синхизитом, TR вхо-

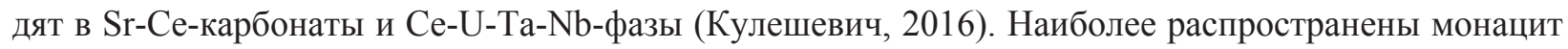
и бастнезит. Монацит ассоциирует с апатитом, он образует самостоятельные зерна, или обрастает кристаллы апатита. В монаците встречаются примеси $\mathrm{Ca}, \mathrm{Sr}, \mathrm{Th}, \mathrm{Si}$, это позволяет предполагать изовалентные изоморфные замещения $\mathrm{Ca}$ на $\mathrm{Sr}$, либо гетеровалентный изоморфизм с замещением $(\mathrm{Ce}+\mathrm{P})$ на $(\mathrm{Ca}+\mathrm{Th}+\mathrm{Si})$. Тонко-пластинчатые и кучные образования REE-фосфатов, обрастающие флогопит и магнетит, отнесены к рабдофаниту $(\mathrm{Ce}, \mathrm{La})\left(\mathrm{PO}_{4}\right) \cdot \mathrm{H}_{2} \mathrm{O}$. TR-карбонаты (бастнезит $(\mathrm{Ce}, \mathrm{La})$ $\left(\mathrm{CO}_{3}\right) \mathrm{F}$ и синхизит $\left.\mathrm{Ca}(\mathrm{Ce}, \mathrm{La})\left(\mathrm{CO}_{3}\right)_{2} \mathrm{~F}\right)$ выдеяются с хлоритом по зонкам рассланцевания, микротрещинкам и в интерстициях между зерен кальцита. При этом карбонатиты приобретают облик рассланцованных пород ржаво-коричневого цвета.

\section{Карбонат-полевошпатовые (Ca-Si) и содалитовые метасоматиты}

Карбонатно-силикатные (Ca-Si) метасоматиты представляют собой плотные белые (до бледно-зеленых) породы (первоначально были названы альбититы). Они сопровождаются гнездовой вкрапленностью Тi-Mn-магнетита и перовскита, иногда содержат в небольшом количестве сульфиды (сфалерит, молибденит) (Кулешевич, 2016). Метасоматиты состоят из Na-Ca-плагиоклаза, нефелина, кальцита, в небольшом количестве содержат диопсид, амфибол, флогопит, эпидот. Плагиоклаз замещается поздним скаполитом. Рудные минералы в метасоматитах представлены MnTi-магнетитом, пирофанитом-манганоильменитом $(\mathrm{Mn}, \mathrm{Fe}) \mathrm{TiO}_{3}$, перовскитом. Магнетит содержит лишь $\mathrm{Al}$ ( $\sim 3$ ат. \%). Пирофанит (Тi 28.51-32.11 \%, Mn 15.84-23.95\%) выделяется в форме ламеллей в магнетите при его распаде и образует самостоятельные зерна; замещает перовскит. Крупные зерна магнетита обычно бывают зональные: в центре - более чистые, во внешней кайме прорастают перовскитом. Перовскит $\mathrm{CaTiO}_{3}$ выделяется как в краевой части магнетита, так и вблизи него на границе с титанитом, образуя самостоятельные зерна. Магнетит и перовскит замещаются титанитом. Метасоматиты содержат наиболее высокие концентрации $\mathrm{Sr}$ и $\mathrm{Zr}$ и их минералы - Sr-кальцит ( $\mathrm{SrO}$ до 2.83-5.6 \%), стронцианит, бадделеит; TR-карбонаты редкие. Bce Sr-минералы образуются позднее. В пирофаните и перовските выделяются тонкие червеобразные зерна, тонкие просечки стронцианита и мелкие кристаллы бадделеита. Кристаллы перовскита имеют зональность: в кайме - более высокостронциевые $(2.2-3.56 \% \mathrm{Sr})$, чем в центре зерен $(0.46 \% \mathrm{Sr})$. Столь значительное количество Sr-минералов в метасоматитах обеспечивает наиболее высокую концентрацию $\mathrm{Sr}$ в них.

Фениты представлены неоднородными породами. Среди них метасоматиты с пятнистой текстурой, обусловленной гнездами синего содалита $\mathrm{Na}_{8}\left(\mathrm{Al}_{6} \mathrm{Si}_{6} \mathrm{O}_{24}\right) \mathrm{Cl}_{2}$, представляют коллекционный материал.

Работа выполняется по теме НИР № ГР АААА-А18-118020290084-7 ИГ КарНЦ РАН.

\section{Литература}

1. Богачев А.И., Зак С.И., Сафронова Г.П., Инина К.А. Геология и петрология Елетьозерского массива габброидных пород Карелии. Изд. АН СССР. Л. 1963. 160 с.

2. Кулешевич Л.В. Редкоземельная минерализация Тикшеозерско-Елетьозерского щелочного комплекса (Северная Карелия) // Геология и полезные ископаемые Карелии. 2016. С. 71-87.

3. Минерально-сырьевая база Республики Карелия. Под ред. Михайлова В.П. Петрозаводск. Карелия. 2006. Кн. 1.280 с.; Кн. 2.356 c.

4. Франтц Н.А., Савва Е.В., Путинцева Е.В. Редкометальные минералы (циркон, пирохлор, бадделеит) карбонатитов Тикшеозерского массива (Северная Карелия). Вестник СПбГУ. 2001. Сер. 7. Вып. 4. № 31. С. 76-83.

5. Щипцов В.В., Скамницкая Л.С., Бубнова Т.П. Промышленные минералы Елетьозерского массива и их аналоги на Фенноскандинавском щите // Геология и полезные ископаемые Карелии. Петрозаводск. 2009. № 11. C. 204-211.

6. Щипцов В.В., Бубнова Т.П., Гаранжа А.В., Скамницкая Л.С., Щипцова Н.И. Геолого-технологическая и экономическая оценка ресурсного потенциала карбонатитов Тикшезерского массива (формация ультраосновных-щелочных пород и карбонатитов) // Геология и полезные ископаемые Карелии. Вып. 2012. C. $159-170$.

7. http://nedrark.karelia.ru/mnia/titan_karelia.htm. 